\title{
Technological Spaces in the Semi-Arid High Plains: Examining Well Ownership and Investment in Water-Saving Appliances
}

\author{
Brock Ternes
}

check for

updates

Citation: Ternes, B. Technological Spaces in the Semi-Arid High Plains: Examining Well Ownership and Investment in Water-Saving Appliances. Water 2021, 13, 365. https:/ / doi.org/10.3390/w13030365

Academic Editor: Mirko Castellini Received: 28 December 2020

Accepted: 26 January 2021

Published: 31 January 2021

Publisher's Note: MDPI stays neutral with regard to jurisdictional claims in published maps and institutional affiliations.

Copyright: (C) 2021 by the author. Licensee MDPI, Basel, Switzerland. This article is an open access article distributed under the terms and conditions of the Creative Commons Attribution (CC BY) license (https:/ / creativecommons.org/licenses/by/ $4.0 /)$.
Department of Sociology and Criminology, University of North Carolina Wilmington, Wilmington, NC 28403, USA; ternesb@uncw.edu

\begin{abstract}
Groundwater depletion has been a consequential problem in Kansas, a drought-prone state widely reliant on the High Plains aquifer. This manuscript explores well ownership's moderating effects on the relationships between awareness of water supplies and the use of water-saving devices. It assesses one of the only quantitative datasets of private water well owners used in social scientific research $(n=864)$ and discusses the intricate results of multi-group structural equation models with respondents organized by their water supplies. Well ownership and water literacy are significantly correlated to owning water-conservation technologies, and well ownership combined with access to municipal water weakens the correlations between awareness and owning water-saving appliances.
\end{abstract}

Keywords: sociology of water use; well owners; groundwater; water supplies; infrastructure; watersaving appliances

\section{Introduction}

Around the planet, groundwater supplies are facing precipitous declines, and one third of Earth's largest aquifers are extremely stressed [1]. As anthropogenic warming intensifies droughts, groundwater losses present a challenging hydroclimatic hazard, and the diminishment of aquifers (underground reservoirs of freshwater) will continue to create global water shortages [2,3]. These vital supplies of freshwater underlie many of the planet's arid and semi-arid regions, and they remain humanity's greatest defense against droughts, though researchers anticipate further dependency on aquifers into the future [4].

Brutal droughts, extreme heat waves, and colossal extractions from tens of thousands of irrigation wells have occasioned terrible declines for one of the largest aquifer systems in the world, the High Plains aquifer. Located in the central United States, this expansive groundwater formation underlies eight states (see Figure 1). The High Plains aquifer contains multiple segments that react differently to overdrafting (the removal of water from of an aquifer faster than it can be regained) and recharge (the natural percolation of surface water into groundwater sources). The disparity between recharge and withdrawal has been so acute that the central and southern portions of the aquifer are undergoing fateful declines [5]. In the state of Kansas, low recharge rates and rapid extractions render segments of the High Plains aquifer virtually unrenewable [6]. The aquifer is now 30\% depleted, and if current rates of extraction continue, it will be $69 \%$ depleted by 2060 [7].

Broadly, the High Plains aquifer is being exploited for its prized irrigation water; this is particularly true in Kansas, which over-allocated irrigation permits for large-capacity wells in the middle twentieth century. Without sweeping curtailments, Kansas will remain "extremely vulnerable to the occurrence of drought" [8] (p. 255). However, exploiting groundwater in the High Plains has sustained global food production for decades. The area overlying the aquifer annually produces more than $\$ 20$ billion worth of crops, and it covers the largest irrigation-sustained cropland on Earth [10,11]. Climate forecasts indicate the High Plains will experience warmer droughts, meaning that the region will require even more groundwater to meet its future needs as water tables continue to shrink [12]. 


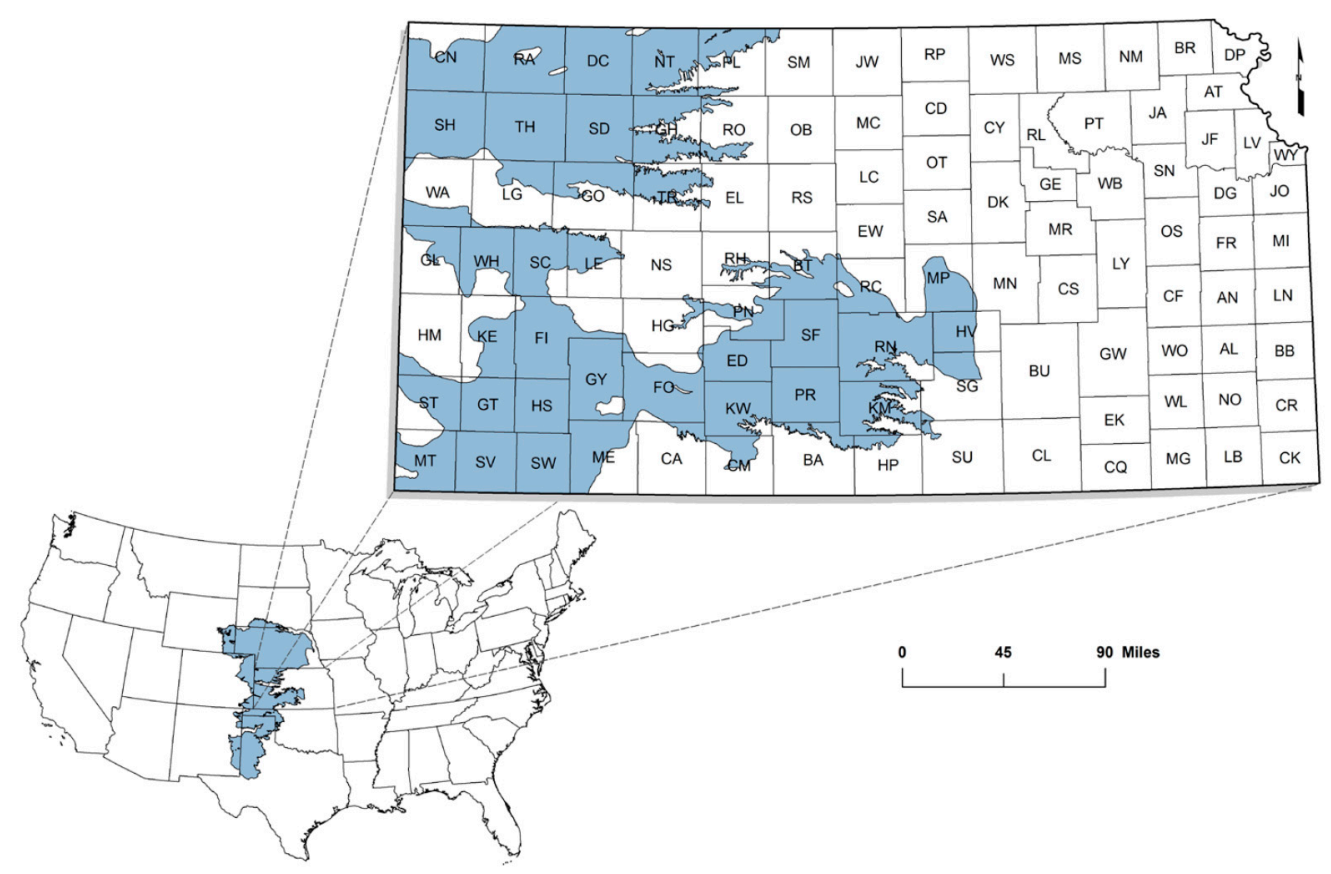

Figure 1. The High Plains aquifer [9].

Drought vulnerability has been a longstanding concern of Kansas policymakers. State law requires water rights owners submit an annual report of their usage to the Kansas Water Office [13], and while Kansas's groundwater regulation mostly focuses on highcapacity wells, the groundwater withdrawals of domestic wells do not have to follow water rights restrictions and remain unmonitored. Since low-capacity wells do not require permits or meters in many parts of the state, if private well owners relied on domestic wells, they could conceivably tap aquifers without acquiring additional permits. Groundwater consumption for domestic usage is not monitored in Kansas, which further complicates well ownership in the Midwest.

Analyzing well ownership in Kansas facilitates an assessment of the relationships between infrastructural conditions and water-conservation. Kansas only monitors highcapacity wells, but evidence suggests that low-capacity wells can also contribute to groundwater losses [14]. Any extraction that exceeds recharge ultimately threatens aquifers and the communities overlying them. Furthermore, if water-conservation technologies are not widely used for both domestic and agricultural purposes, then domestic usage could eventually compete with the water needed for food production. As climate change has a "growing impact on agriculture due to changing rainfall patterns ... warming temperatures, aridity, and greater uncertainty" [15] (p. 109), conserving groundwater will remain paramount for weathering the Anthropocene. Examining how water-saving technologies are utilized within specific groundwater formations and infrastructural systems can provide insight into well owners' management of their water supplies. Aquifers and well owners form a unified socio-ecological system, and looking into the technologies well owners use to conserve water is beneficial for preserving aquifers.

This study of water conservation demonstrates how household water supplies shape Kansans' investment in water-saving technologies. Investigating the individuals who depend on the High Plains aquifer, this research scrutinized Kansans' water literacy (the understanding of water supplies and how water is used) and how water supply infrastructure is associated with owning water efficient appliances. Generally, the paper unpacks the technologies affected by well ownership. What are well owners' and non-well owners' investments in water-saving appliances? Are relationships between water supply awareness and water conservation arbitrated by systems of water provision? Ultimately, this project demonstrates that water supplies contour the associations between the awareness of water supplies and using water-saving appliances. The present study assessed the ownership of 
water-conservation technologies among Kansans with different water supply systems. It found that well ownership and water literacy are significantly correlated to owning waterconservation technologies-but those relationships change across different infrastructural contexts. As the climate of the High Plains becomes less predictable, communities prone to drought must acquire a precise understanding of the public's deployment of water-saving technologies to prepare for a new hydrologic reality defined by more frequent and intense water shortages.

With the prospect of warmer droughts looming, analyzing water supply infrastructures will be critical. The resilience of rural communities rests on environmental awareness and conservation efforts, since groundwater is the drinking water source for $90 \%$ of the rural population in the United States and $80 \%$ of rural Canadians [16,17]. Private well owners are susceptible to groundwater contamination and reduced well yields, and they are disproportionately burdened by groundwater loss compared to citizens with municipally provided water. The next section outlines the literature on water supply infrastructure and consumption, and it discusses how water conservation has been studied.

\section{Literature Review and Framing}

In many ways, water infrastructure distinguishes urban communities (which provide water to residents via centralized supplies) from rural communities (where agricultural water usage and groundwater extractions provided by private wells are common). Contrasting public and private water supplies reveals how water consumption is defined across urban and rural contexts; additionally, modern drinking sources fundamentally revolutionized standards of water usage. As water became easily accessible within cities, new interpretations of cleanliness took over everyday life. Rates of consumption increased as plumbing became omnipresent in cities and urbanites affixed status to improved hygiene $[18,19]$. Since technological backdrops shape water-use routines, individual water usage is a consequence of material settings [19]. While the literature on water supply infrastructure spotlights urban centers with consolidated utilities [20-22], this project probed how private wells change water-conservation efforts.

Infrastructure arranges individuals' interactions with-and knowledge of - natural resources; municipal water outreach campaigns show that most citizens in the United States do not know where their water comes from [23]. Grasping environmental issues and awareness of personal involvement in natural resource decline motivates pro-environmental behavior (PEB) [24-26], and proximity to environmental hazards can impel PEBs [27,28]. This article connects environmental awareness to water saving while assessing differences in water supply infrastructure. By framing well owners within a distinct hydrologic setting, the present study shows how shifts in infrastructural context relate to investments in water-saving technologies.

Well owners have legitimate uneasiness about water security, including the regional impacts of climate change (specifically floods and droughts), groundwater contamination, hydraulic fracturing, and aging septic systems [29]. Studying environmental perceptions within specific infrastructural systems can improve how practice theorists [30,31] view consumption. Water conservation is an emergent property of peoples' involvement with their technical surroundings, " ... Infrastructure does not dictate habits, but it does emit cues that are responsible for physical and symbolic channeling of . . . attractive opportunities [for behavior] ... " [32] (p. 118). Theories of practice have yet to explore the considerable variation in water supplies, although individuals embedded within private infrastructures likely make distinctive investments in water-efficient technologies. Practice scholarship [32] analyzes the structural conditions that guide routines, and this project assessed how spatiality influences water literacy and the propensity to use water-saving appliances.

Well owners monitor agricultural runoff, well yields, pumping costs, depth to the water tables, and well water quality; therefore, they constitute a "community of practice" [33,34], a group defined by similar routines and boundaries of performance. Studying well ownership can expose new ways to investigate the propensity to save water via effi- 
cient technologies. Analyzing well owners and non-well owners empowers a closer look at the relationships between environmentalism and environmental awareness. Different supplies provoke different demands; municipal water systems can deliver seemingly endless supplies of safe, affordable water and therefore changed the evolution of domestic water usage [35-37]. On the other hand, wells are more modest water provision instruments and draw from nearby, finite groundwater sources. Private wells, due to their limited access and reliance on groundwater supplies, are likely the sites of greater water-conservation adaptation strategies, and it seems appropriate to expect structurally based patterns of conservation efforts.

The contexts of private wells and centralized public infrastructures are different "systems of provision" [38] — the activities, technologies, and institutional arrangements that unite to provide a good or service. Systems of provision include the material constraints that guide performances related to water consumption; therefore, it should be expected that the infrastructure delivering water shapes water literacy and the use of appliances that save water. This exploration of different systems of provision outlines patterns of consumption and resource awareness, and it applies the concept of spatiality to water supplies. Interview data indicated that farmers attribute conservation practices to an upbringing without running water, and households deprived of municipal supplies develop unique watering schedules to keep their usage to a minimum [39,40]. Accessing water without public infrastructure requires the exhaustive chores of digging a private well or hauling water; therefore, differences of spatiality are likely associated with the presence of water-saving appliances.

The sociology of water usage $[20,21]$ has not investigated private wells, even though sociologists have called for examinations of "relationships and interactions between processes of supply and the dynamics of consumption" [20] (p. 37). Extant water provision research generally defines water supply infrastructure as a centrally controlled utility within urban contexts, a definition that overlooks the infrastructural differences associated with rural sources. While water experts have explored water consumption's "technological, infrastructural, or behavior-based changes" [21] (p. 1020), they have not sufficiently analyzed how wells, as systems of water provision, contribute to environmental decisions. This research asks how non-centralized water supplies effect water conservation in Kansas. An online survey of well-owning and non-well-owning Kansans' investments in water-saving appliances was conducted to test whether owning efficient watering technologies was influenced by infrastructure.

\section{Materials and Methods}

The researcher mailed 7021 notification postcards inviting Kansas well owners to participate in an online survey that measured their household water supply, reactions to droughts, and awareness of water policies and supplies. The well owners' home addresses were obtained from the Kansas Geological Survey's database of well completion records. Additionally, a sample of 420 Kansans was obtained from Qualtrics, which had a high percentage of non-well owners. Qualtrics uses a sampling frame from the Survey Sampling International's (SSI) multi-sourcing panel recruitment model, which has a large number of diverse frames that generate representative random samples. This strategy enabled research generalizable to Kansas and comparisons of well owners to non-well owners.

This survey generated one of the only quantitative datasets on well owners used for social science research. Survey responses were collected in 2015; the overall response rate for the postcards sent to well owners was $6.3 \%$, which produced 444 respondents. The timing of this data collection coincided with a number of important events, as 2015 was an important year for the High Plains aquifer. Kansas was clawing out of one of its worst droughts in several decades, and 2015 was the first full year of the "Long-Term Vision for the Future of Water Supply in Kansas," a plan for securing the state's water for the next fifty years. In response to irrigation's demand for tremendous amounts of water, the Kansas Water Office and US Army Corps of Engineers studied the feasibility of diverting 
water from the Missouri River to western Kansas. Known as the Kansas Aqueduct, this proposal was first drafted in 1982 and revisited in January 2015, when it was established that the 360 -mile $(580 \mathrm{~km})$ aqueduct would take 20 years to construct and cost $\$ 18$ billion. Given the statewide concerns surrounding drought vulnerability and groundwater losses, 2015 was an opportune time to collect data on well owners in Kansas.

The entire dataset was comprised of 864 respondents, 452 non-well owners (52\%), and 412 well owners. Of those well owners, 20 were former well owners, 143 were without municipal water supplies, and 249 had both wells and municipal water. This research made strides towards understanding the generalizability of Kansans' relationships with water within different infrastructural contexts.

To analyze these data, the researcher performed multi-group structural equation modeling (SEM) with respondents organized by household water supplies, well owners who were without municipal water connections ("off the grid"), well owners with municipal water connections, and well owners who had domestic, lawn and garden, feedlot, and irrigation wells. SEM is a practical multivariate technique that estimates constructs, which are collections of related survey items. Constructs are latent concepts that are not measured directly; their qualities are inferred by relying on a collection of variables selected as proxies. The indicators measuring respondents' investment in water conservation and awareness of water supplies were organized so that they accurately represented the pertinent constructs by occasionally applying an organizational technique known as parceling, whereby modelers take two or more items and average them and then use the average as a manifest indicator rather than relying on individual items. This project's analytical software was Mplus, a computer program designed for SEM. SEM estimates causal relations between constructs. A study of causality between these associated constructs, SEM is a complex series of hypotheses that consist of a measurement model (a set of multiple variables that form latent constructs) and a path model that describes the relations of dependency between the constructs.

Two constructs were at the heart of this analysis: one measured investment in indoor water-saving appliances (the information shared by indicators measuring if respondents own a low-flow showerhead, a low-flow toilet, and a water-saving washing machine); the other measured investment in outdoor water-saving appliances (the indicators of which were the ownership of timed sprinkler systems and drip irrigation).

The outcome variables were regressed on a construct that measured water supply awareness (which included three parceled indicators measuring familiarity with xeriscaping and greywater systems; familiarity with the High Plains aquifer and groundwater management districts; and familiarity with the Kansas Water Office, the Governor's LongTerm Vision, and the Kansas Aqueduct; as well as an indicator measuring if respondents could correctly identify irrigation as the biggest water user in Kansas). Since agricultural water usage is the biggest groundwater consumer in Kansas, it was important to include drip irrigation as an indicator for the construct measuring outdoor investments.

Factorial invariance was tested for using a goodness-of-fit index (GFI) that examined the change in the comparative fit index (CFI; a comparison of the fit of a target model to the fit of a null model with a cut-off for acceptable fit of greater than 0.90) from each model. Also provided are RMSEAs, or root mean square errors of approximation, which is a parsimony adjusted index to determine fit with a threshold of less than 0.08 for adequate fit, and chi-square values, which gauge discrepancies between observed and expected values. These are among the most commonly reported fit indices for SEM. Following the standards laid out by previous SEM researchers who used the GFI [41,42], these constructs were comparable across groups of well owners. The models examined how the construct measuring water literacy directly influenced the ownership of indoor and outdoor watersaving technologies. 


\section{Multi-Group Data and Moderation}

How do water-conservation efforts change across communities when organizing Kansans along the lines of well ownership? Multi-group SEM was employed to measure how constructs performed in certain groups, and these respondents were organized based on their household water supply. Watering practices are nested within distinct contexts. Community resilience to aquifer decline is a complex set of interactions that occur within larger hydrologic and agronomic systems that reveals the nested qualities of groundwater communities: they exist within precise infrastructural settings, experience different levels of overdrafting and recharge, and reside above specific supplies of groundwater. Analyzing Kansas well owners without considering the nested effects of water supplies ignores the glaring infrastructural differences between well-owning and non-well-owning Kansans; clarifying how water usage is embedded in unique systems of provision was a key goal for this research.

Moderation is an important causal effect that had implications for this research agenda, which hypothesized that the relationship between water literacy and water conservation would be moderated by the well's function. The type of well in use (domestic, lawn and garden, irrigation, etc.) may influence the association between watering routines and water supply infrastructure. Low-capacity domestic wells may not have the pumping capabilities, depth, or groundwater supply to deliver an abundance of water to their owners' households. This would obviously limit domestic usage and lead to water-conservation routines out of necessity. While agricultural (e.g., irrigation and livestock) wells often do not provide households with water, the owners of these types of wells may be motivated to conserve water domestically out of stewardship for their groundwater supplies. Water is a metabolic piece of urban and rural life in Kansas, and it remains differentiated in its use. The theme of moderation is therefore central to water management.

Discovering that the relationships between water awareness and using water-saving devices are moderated by the type of well in use would reveal an understudied association between resource conservation and water supply infrastructure. Social scientists studying water management hold that separate groups have distinct interests in conserving their water supply [43]. Moderation should therefore be expected and empirically demonstrated among well owners, specifically regarding their well's function. The next brief section examines well ownership's role as a predictor with a simple SEM in which owning indoor and outdoor water-saving technologies were outcome constructs. These results, and the following section covering multi-group modeling, describe the regression coefficients between the dependent and independent constructs; consult the Appendix A for the complete results of the factor loadings, residual variance parameters, and standard errors of the indicators.

\section{Results}

\subsection{Well Ownership and Investment in Water-Saving Appliances}

Figure 2 shows the model regressing the outcome constructs of investing in watersaving devices on the independent variable measuring well ownership. Well ownership was found to have a positive association with indoor water-saving investments $(b=0.305$; $p<0.001)$ and a stronger positive correlation with outdoor water-saving devices $(b=0.452$; $p<0.001)$. The model supported the claim that well ownership is an important predictor for many of the constructs of interest, along with geography, sex, income, and age [44]. How do these constructs influence each other in a structural equation model, and does well ownership change the associations between these constructs? How does a well's specific function change the relationship between water usage and well reliance? Are the relationships different for "off the grid" well owners compared to well owners who have access to municipal water? The next section answers these questions by reviewing the results of multi-group structural equation models. 


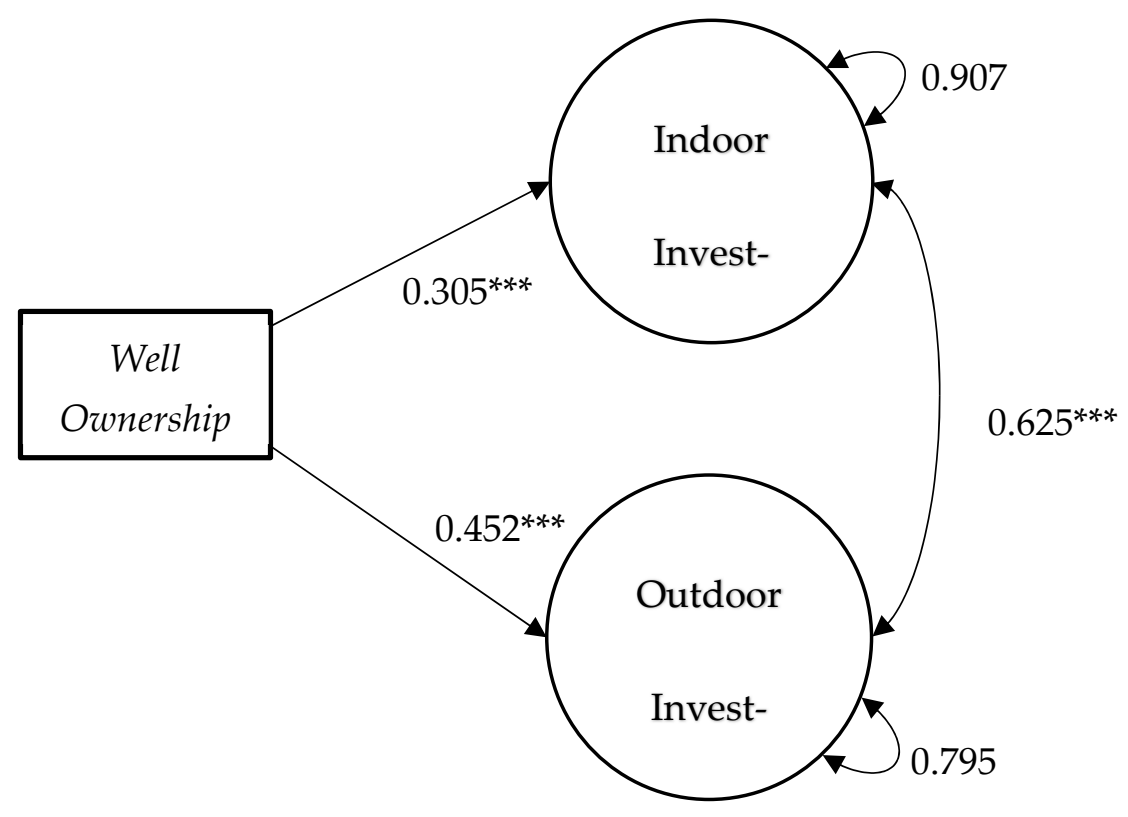

Model Fit: $\chi 2(8)=18.739 ; p<0.001 ; \mathrm{CFI}=0.979 ;$ RMSEA $=0.040$

${ }^{*} p<0.05 ;{ }^{* *} p<0.01 ;{ }^{* * *} p<0.001$.

Figure 2. Model of owning water-saving appliances for indoor and outdoor usage regressed on well ownership ( $n=847)$. CFI: comparative fit index; RMSEA: root mean square error of approximation.

\subsection{Moderation: Well Ownership, Municipal Connections, and Specific Well Function}

To examine how water supplies moderate the associations between water supply awareness and investing in water-saving technologies, a series of multi-group structural equation models organized respondents along the boundaries of water supply infrastructure. The results are sequenced as follows: first, they demonstrate how levels of water-related knowledge correlate to the ownership of water-saving technologies for well owners and non-well owners, then for well owners who do not have municipal water connections and those who have public utilities, and finally for owners of different types of wells (domestic, lawn and garden, feedlot, and irrigation).

\subsection{Water-Saving Appliances and Water Literacy}

\subsubsection{Non-well Owners and Well Owners}

Figures 3 and 4 depict the models of the multi-group analysis for non-well owners and well owners. For non-well owners, the correlations between awareness and indoor investments $(b=0.471 ; p<0.001)$ and outdoor investments $(b=0.579 ; p<0.001)$ were found to be positive and significant. The same could be said about well owners' slope for indoor appliances regressed on awareness levels $(b=0.338 ; p<0.001)$ and their outdoor appliances regressed on awareness levels $(b=0.438 ; p<0.01)$. The standardized beta values-which represented the associations between the constructs-for awareness levels and investments among well owners were weaker than they were for non-well owners.

\subsubsection{Well Owners with and without Municipal Water Connections}

Examining the multi-group SEMs that organized well-owning respondents by well owners without a connection to public utilities and well owners with connections to public utilities showed how water usage and well ownership is moderated by the presence or absence of publicly provided water (Figures 5 and 6 ). For well owners with no public water, there was a positive association between awareness and investing in indoor water-saving appliances $(b=0.406 ; p<0.01)$ and a stronger positive relationship between awareness and outdoor investments $(b=0.777 ; p<0.01)$. For well owners with a public water connection, the associations between awareness levels and indoor and outdoor water- 
saving investments were not significant, a key difference compared to the off the grid well owners. The combination of public and private water supplies was found to moderate the association between knowledge of water supplies and owning water-saving appliances.

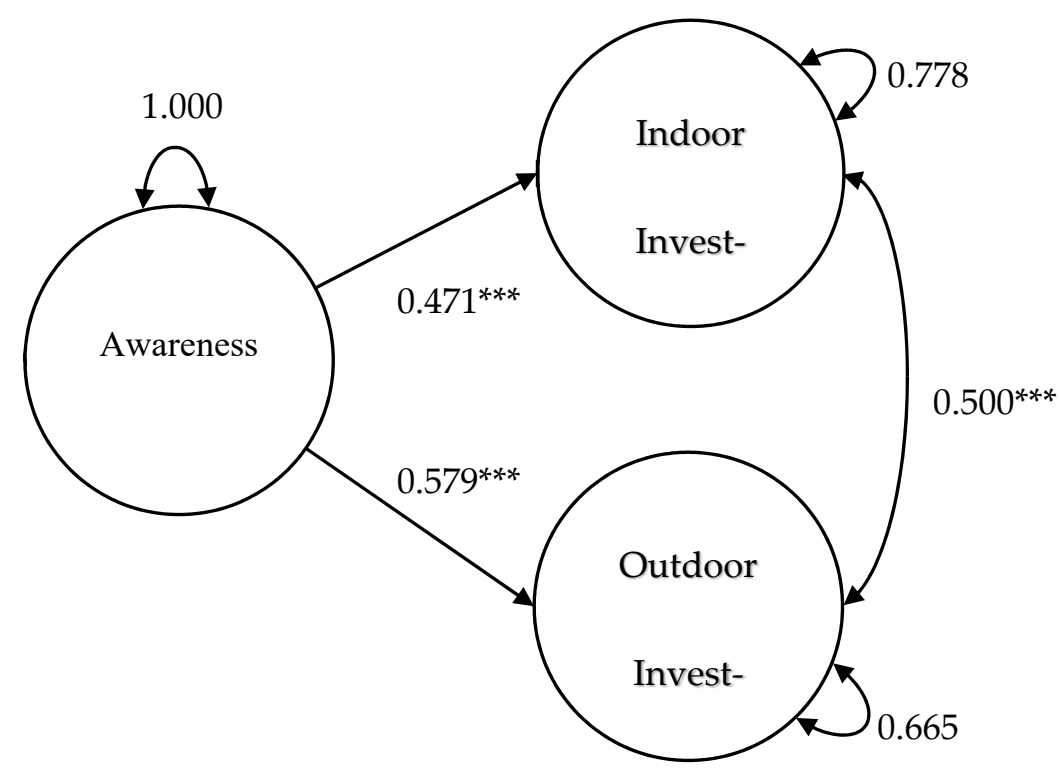

Model Fit: $\chi \mathbf{2}(\mathbf{6 2})=101.142 ; p<0.01 ; \mathrm{CFI}=0.943 ; \mathrm{RMSEA}=0.038$ ${ }^{*} p<0.05 ;{ }^{* *} p<0.01 ;{ }^{* * *} p<0.001$.

Figure 3. Model of owning water-saving appliances for indoor and outdoor usage regressed on awareness of water supplies for non-well owners $(n=448)$.

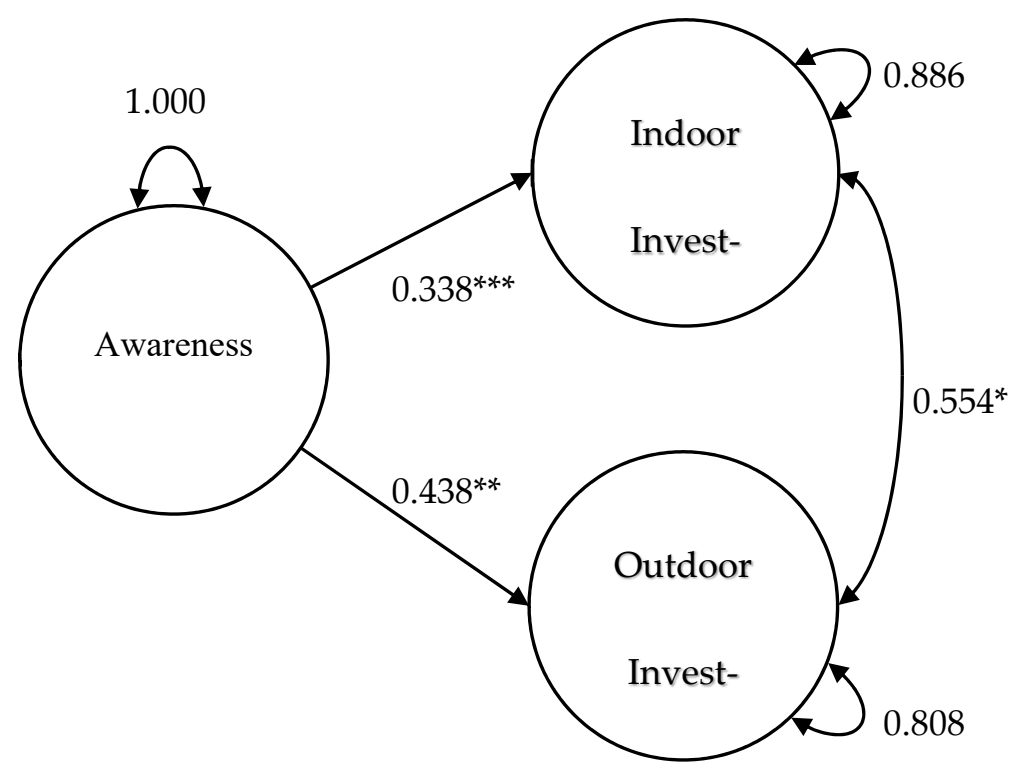

Model Fit: $\chi \mathbf{2}(\mathbf{6 2})=101.142 ; p<0.01 ; \mathrm{CFI}=0.943$; RMSEA $=0.038$ ${ }^{*} p<0.05 ;{ }^{* *} p<0.01 ; * * *<0.001$.

Figure 4. Model of owning water-saving appliances for indoor and outdoor usage regressed on awareness of water supplies for well owners $(n=407)$. 


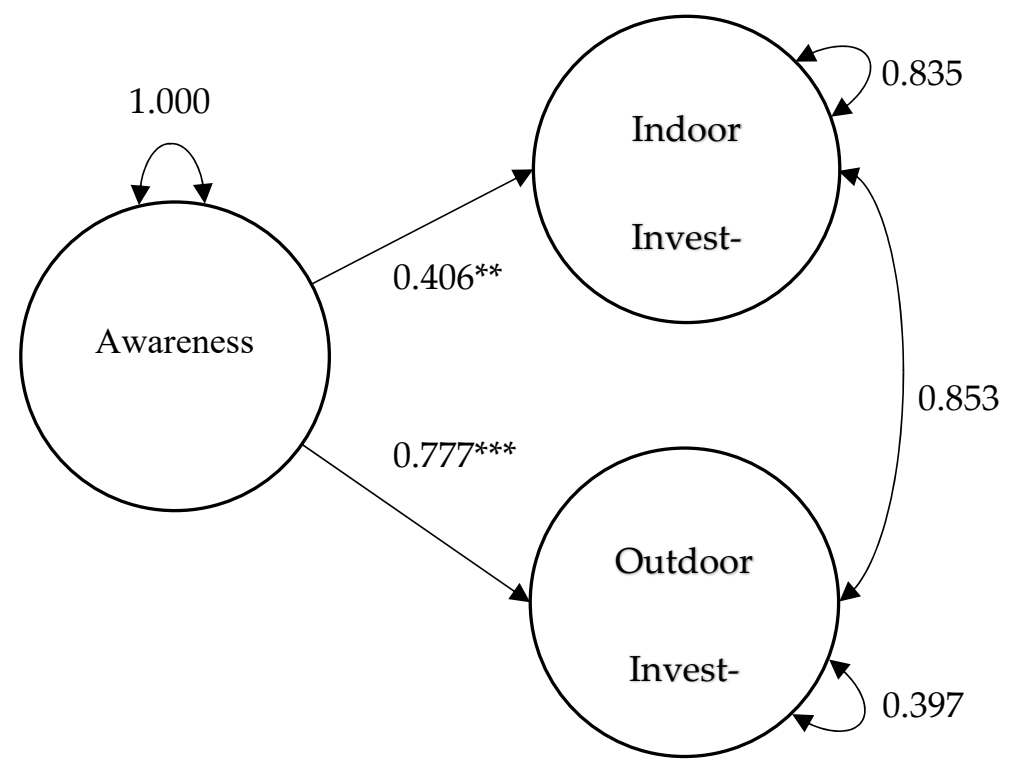

Model Fit: $\chi 2(62)=86.019 ; p<0.05 ; \mathrm{CFI}=0.902 ;$ RMSEA $=0.045$ ${ }^{*} p<0.05$;** $p<0.01$; *** $p<0.001$

Figure 5. Model of owning water-saving appliances for indoor and outdoor usage regressed on awareness of water supplies for well owners without municipal connections $(n=141)$.

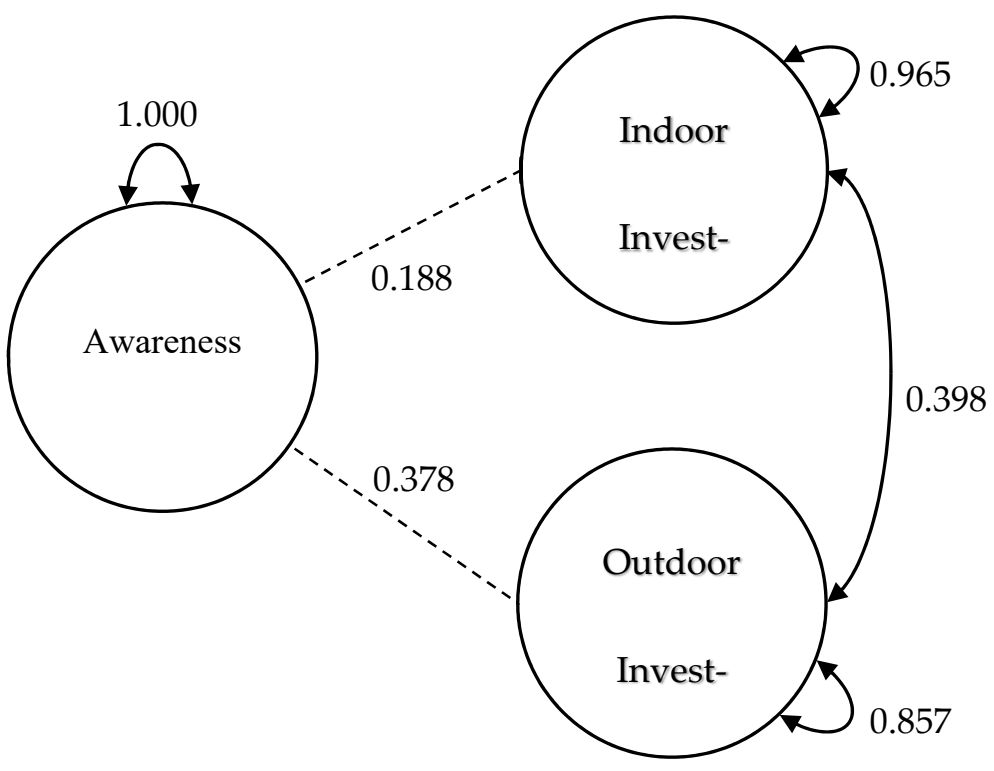

Model Fit: $\chi 2(62)=86.019 ; p<0.05 ;$ CFI $=0.902 ;$ RMSEA $=0.045$ ${ }^{*} p<0.05 ; * * \quad p<0.01 ; * * *<0.001$

Figure 6. Model of owning water-saving appliances for indoor and outdoor usage regressed on awareness of water supplies for well owners with municipal connections $(n=246)$.

\subsubsection{Domestic, Lawn and Garden, Feedlot, and Irrigation Well Owners}

Figures 7-10 show the models for each specific type of well owner. The positive slopes between water supply awareness levels and owning indoor water-saving appliances and between awareness and owning outdoor water-saving appliances were only significant for domestic well owners ( $b=0.514$ and $p<0.01 ; b=0.578$, and $p<0.01$, respectively). Respondents who owned lawn and garden wells, feedlot wells, and irrigation wells were found to have no significant correlations between these constructs. Therefore, the function 
of the well changes the association between water supply awareness and investments; it was a moderated association. Increasing awareness levels could theoretically yield a significantly higher investment in water-saving technologies for domestic well owners than for well owners without domestic wells. Overall, familiarity with water supplies was found to be positively associated with owning such appliances, and these results suggested that owning a domestic well changes the association between awareness of water supplies and investing in water-saving appliances.

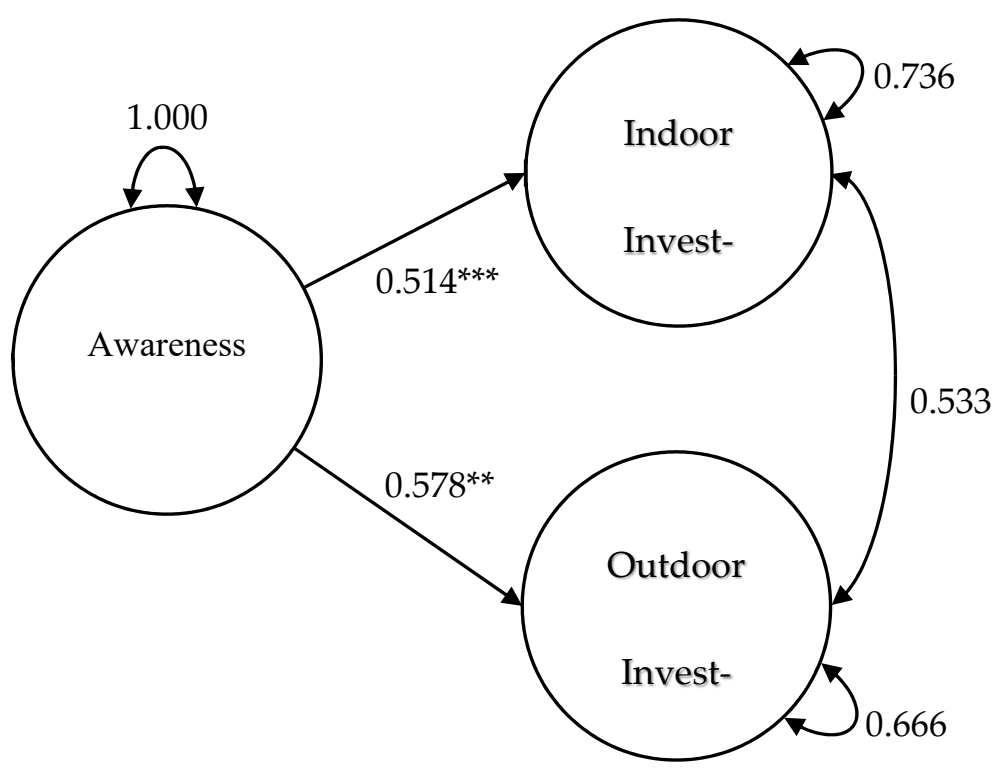

Model Fit: $\chi 2(135)=157.232 ; p<0.10 ; \mathrm{CFI}=0.913 ;$ RMSEA $=0.040$ ${ }^{*} p<0.05 ; * * 0.01 ;{ }^{* * *} p<0.001$

Figure 7. Model of owning water-saving appliances for indoor and outdoor usage regressed on awareness of water supplies for domestic well owners $(n=145)$.

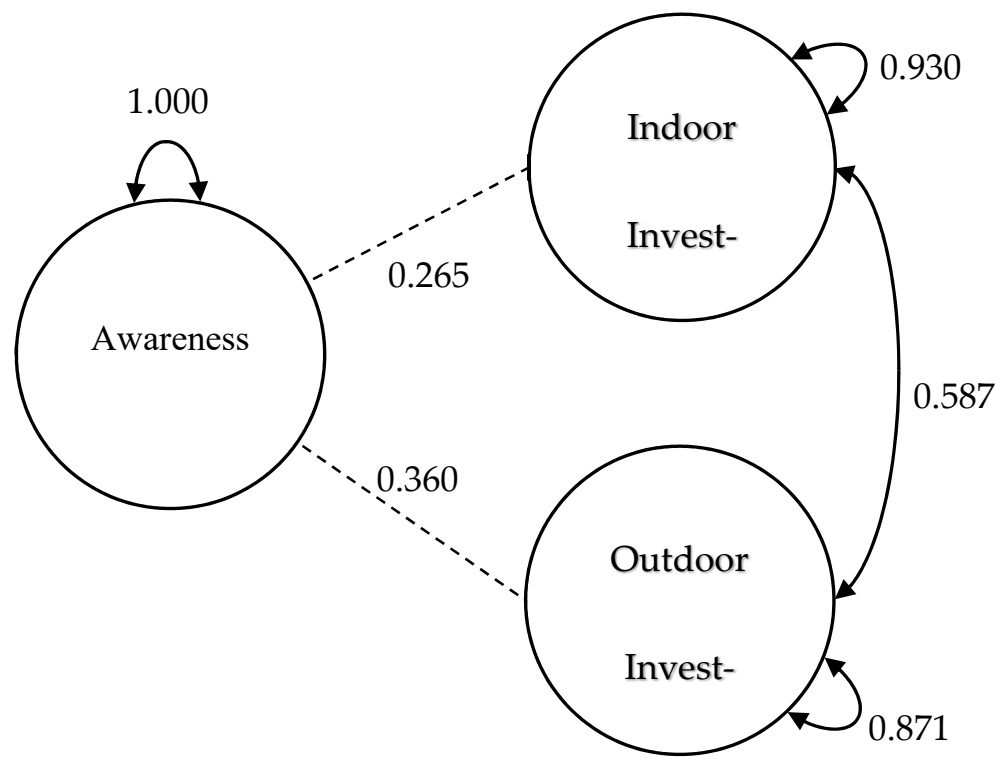

Model Fit: $\chi 2(135)=157.232 ; p<0.10 ; \mathrm{CFI}=0.913$; RMSEA $=0.040$

${ }^{*} p<0.05 ;{ }^{* *} p<0.01 ;{ }^{* *} p<0.001$

Figure 8. Model of owning water-saving appliances for indoor and outdoor usage regressed on awareness of water supplies for lawn and garden well owners $(n=135)$. 


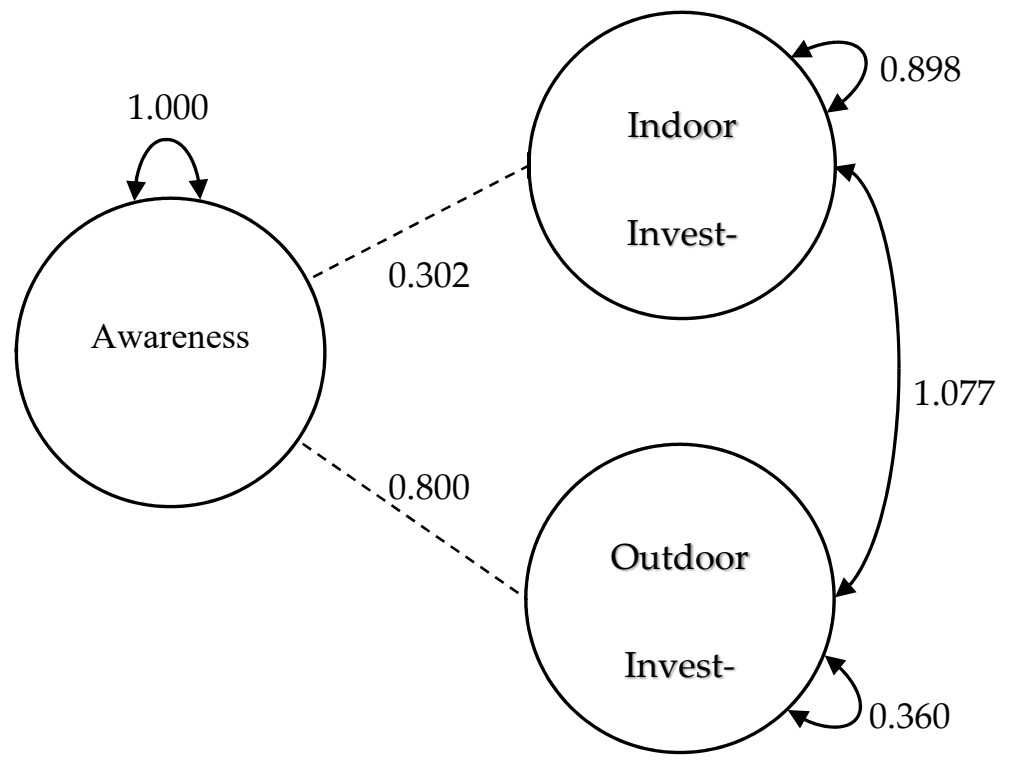

Model Fit: $\chi 2(135)=157.232 ; p<0.10 ; \mathrm{CFI}=0.913 ;$ RMSEA $=0.040$

${ }^{*} p<0.05 ;{ }^{* *} p<0.01 ;{ }^{* * *} p<0.001$

Figure 9. Model of owning water-saving appliances for indoor and outdoor usage regressed on awareness of water supplies for feedlot well owners $(n=66)$.

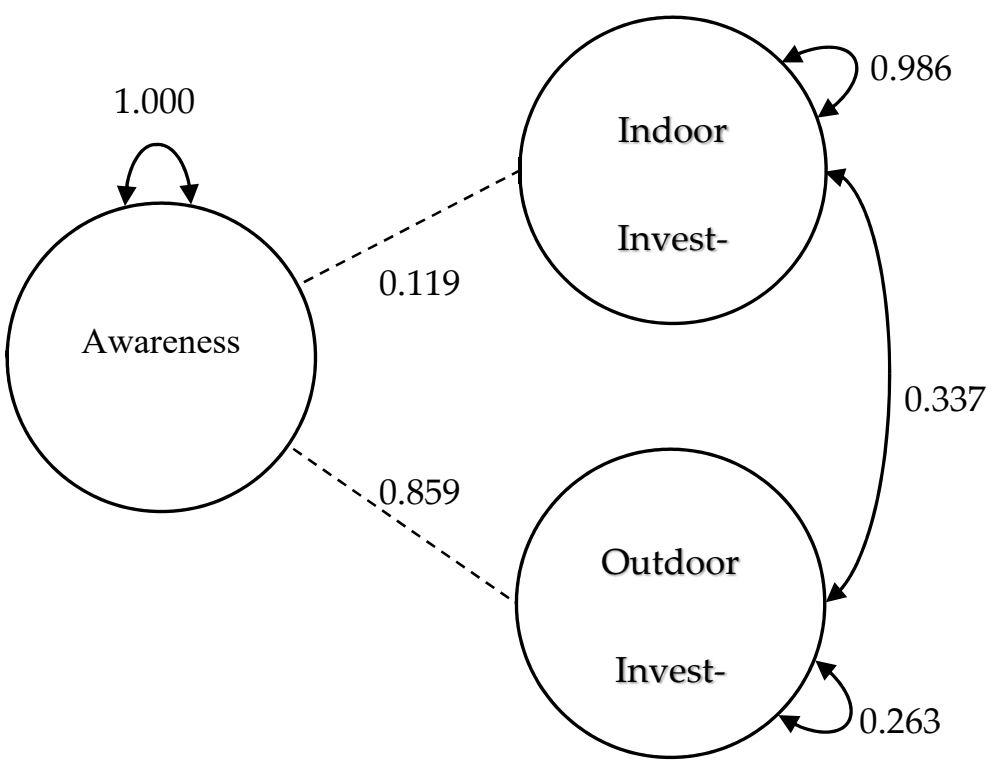

Model Fit: $\chi 2(135)=157.232 ; p<0.10 ; \mathrm{CFI}=0.913$; RMSEA $=0.040$

${ }^{*} p<0.05 ;{ }^{* *} p<0.01 ; * * * 0.001$

Figure 10. Model of owning water-saving appliances for indoor and outdoor usage regressed on awareness of water supplies for irrigation well owners $(n=61)$.

Therefore, water supply infrastructure should be analyzed as an important moderating variable for researchers who investigate resource conservation via technological efficiencies and cognizance of natural resources.

Four valuable findings arose. First, well ownership was found to be significantly correlated to owning water-conservation technologies. Second, combining public and private water supplies was found to slightly weaken the relationships between awareness and owning water-saving appliances. Water supply awareness was found to have a significant positive correlation with owning efficient watering devices for off the grid well 
owners but not for well owners who also have city water. Third, the well's function was found to change the association between water supply awareness and investments; it was a moderated association. Increasing awareness levels could theoretically yield a significantly higher investment in water-saving technologies for domestic well owners than for well owners without domestic wells. Fourth, awareness levels were positively associated with the ownership of water-saving appliances.

\section{Discussion}

The positive associations between well ownership and awareness levels with investments in efficient watering technologies is a promising finding that implies a commitment to conservation. Well owners require a series of "environmental heuristics" [45] to establish how to live sustainably. Such heuristics can harness the social rationale for conserving resources in a way that fits practically into daily life and would require well owners to make informed decisions about cautiously extracting groundwater. A communal identity can influence individuals' behaviors and coping reactions to disasters; residents living in drought-prone areas tend to integrate adaptation strategies into their daily lives. Well owners, while responsible for groundwater extractions, have an important responsibility as aquifer caretakers. Paradoxically, the very people who are most active in the depletion of aquifers are also their guardians; well owners' decisions play a large role in the severity of overdrafts. Groundwater citizenship [46] above the Ogallala Aquifer entails a reliance on groundwater during times of aridity, but that does not necessarily imply irresponsible resource usage. This recasting of stewardship follows Lister's [47] and Curtin's [48] arguments that citizenship should be described in terms of the nested sites in which practices of citizenship are performed and individuals establish their identity as ecological citizens in relation to their natural ecosystems. The book New Farmers [49], which chronicled the changing face of Kansas farmers, supports the claim that farming - when done correctly - translates into acts of preservation.

These results expose another possibility. Conceivably, well ownership can enable what Szasz [50] characterized as an "inverted quarantine," half-measures that consumers take to modestly adapt to climate change or resource scarcity. Instead of politically mobilizing, letting their lawns fend for themselves, or redefining their watering routines, people install a lawn and garden well and invest in efficient watering devices so that they can continue to use water "normally" without having to pay higher water bills or consciously change their behaviors during droughts. Instead of aggressively switching to a low-water lifestyle, small capacity lawn and garden wells can enable water consumption for some Kansans (as opposed to reducing it).

The research questions probing whether well function changes Kansans' relationships with water were designed to explore the influence of moderation and nested effects via multi-group analysis. The "liquid dynamics" [51]—the interactions between the social, technological, and hydrological dimensions of water systems-vary across Kansas due to the reliance on surface or groundwater supplies. Non-well owners and well owners were both found to have positive associations between the constructs measuring awareness and water-saving devices, but the correlations were found to be slightly weaker for well owners. Isolating the well owners specifically and conducting a multi-group model along the lines of the type of well they use suggested that domestic wells are the only type of well that yield a significant positive relationship between levels of water supply awareness and investments in water-saving technology. The significant correlations between water supply awareness and investing in efficient watering technologies appeared to be stronger for well owners without city water than for well owners with municipal connections. While owning water-saving appliances was not significantly predicted by awareness levels for lawn and garden, feedlot, and irrigation well owners, it was for domestic well owners. These distinctions were evidence of nested effects, findings similar to scholarship probing well owners' reactions to droughts [52].

When measuring the outcomes of investing in water-saving appliances, familiarity with water supplies was found to be positively correlated with the outcome constructs. 
This implies that increasing Kansans' levels of awareness would theoretically increase the ownership of water saving devices, and increasing public awareness of water usage is a precondition for better water management. These results suggest that water supply infrastructure is an important component of citizens' resource awareness and investments in efficient technologies, which is similar to the echoes of previous research providing evidence that environmental considerations are influential precursors of PEBs [53].

Owning a well apparently inspires water conservation that is enabled through the use of water-saving devices. Furthermore, well function changes the relationship between knowledge of water supplies and investing in water-saving appliances. Overall, Kansans with private wells could be electing to save water through technological fixes. While it is challenging to establish a sense of well owners' specific daily routines with these findings, their awareness levels and commitment to technological adjustments are encouraging. Largely, infrastructural differences remain an important component for researchers interested in nested effects. Society's embeddedness within ecosystems requires what Catton and Dunlap $[54,55]$ called a new ecological paradigm to ensure that sociologists consider the natural limits of human activities. This research contributes to this paradigm by studying the behaviors, awareness, and attitudes of water consumption with separate technological backdrops via the implementation of multi-group work that required a perspective that acknowledges the importance of nested effects and private, systemic nuances that may not have been detected if all of the data were to be analyzed at the state level.

As stated on numerous occasions, this study frames well owners as a distinct social group defined by their practices and their exposure to groundwater depletion and drought. According to the project's findings, this claim appears to be accurate but heavily nuanced. Well ownership increases technological conservation efforts, but the positive association between water literacy and using efficient appliances is not always significant in certain hydrologic contexts. Household water supplies are important predictors-and moderatorsof watering routines, and they should be included in future research on water conservation.

\section{Conclusions}

The High Plains aquifer is being tapped beyond its natural rates of replenishment, which has profound implications for sustaining drought-prone communities in Midwestern states like Kansas. This study examined how private water wells influence conservation by comparing the watering technologies of well owners to those of non-well owners across the state. The results indicated that controlling for water supplies uncovers important differences across many associations. Investments in indoor and outdoor water-saving devices were found to be frequently correlated with levels of water literacy for these respondents, who had been delineated along boundaries of water supplies. Well ownership was found to change some associations surrounding water supply awareness and investments in efficient watering appliances.

Seeing modernity through the prism and distribution of infrastructures affords a new understanding of how modern interactions with nature have been shaped by the specific technological spaces of drinking water supplies. Water consumption is firmly rooted in the organization of infrastructural and social systems, and meaningful conservation efforts require fundamental changes to these systems. This research explored how watering practices and environmental awareness are formed around larger socio-ecological structures-aquifers, aridity, and systems of water provision. By establishing how hydrologic infrastructure organizes citizens' relationships with water, this project demonstrates how material assemblages have the potential to transform environmental dispositions. Individuals with private water wells can be framed as a distinct social group that is disproportionately burdened by drought, and well owners represent a unique community of practice that can improve how sociologists understand water supply management. Researching well owners' technological investments, awareness of water supplies, and acts of environmental stewardship will be key to aquifer preservation in the Anthropocene. 
Funding: This research was partially supported by the University of Kansas under the Doctoral Student Research Grant, and the Institute for Policy \& Social Research at the University of Kansas under the Doctoral Research Fellows Grant. The Article Processing Charge was funded by the Randall Library Open Access Publication Fund at the University of North Carolina Wilmington.

Institutional Review Board Statement: The study was conducted according to the guidelines of the Human Subjects Committee Lawrence Campus, and approved by the Institutional Review Board of the University of Kansas (protocol code \#00001050; date of approval October 28, 2014).

Informed Consent Statement: Informed consent was obtained from all subjects involved in the study.

Data Availability Statement: The data presented in this study are available on request from the corresponding author. The dataset is not publicly available due to its sensitive information.

Acknowledgments: The author effusively thanks Paul Stock, Bob Antonio, David Smith, Ebenezer Obadare, and Terry Loecke at the University of Kansas, Todd Little at Texas Tech University, and Stephanie Crowe at the University of North Carolina Wilmington. Thanks to Valerie Peterson, Cassie Butts, Sofiia Filatova, Yulduz Kuchkarova, Liz Blackburn, Halle McCourt, Katelyn Whitt, Chelsea Martell, and Murphy Maiden for their research assistance. The editorial staff and reviewers at Water offered perceptive feedback on this manuscript and were extraordinarily punctual.

Conflicts of Interest: The author declares no conflict of interest.

\section{Appendix A. SEM Measures}

Table A1. Standardized model results of owning water-saving appliances for appliances for indoor and outdoor usage regressed on well ownership.

\begin{tabular}{llll}
\hline & Factor Loadings & Residual Variances & S.E. \\
\hline Indoor water-saving appliances & & & \\
\hline Low-flow showerhead & 0.685 & 0.462 & 0.046 \\
\hline Low-flow toilet & 0.790 & 0.137 & 0.043 \\
\hline Water-efficient washing machine & 0.600 & 0.212 & 0.047 \\
\hline Outdoor water-saving appliances & & & 0.049 \\
\hline Timed sprinklers & 0.615 & 0.795 & 0.049 \\
\hline Irrigate more & 0.615 & 1.471 &
\end{tabular}

Table A2. Standardized model results of owning water-saving appliances for appliances for indoor and outdoor usage regressed on awareness levels for non-well owners $(n=448)$.

\begin{tabular}{llll}
\hline & Factor Loadings & Residual Variance & S.E. \\
\hline Awareness & & & \\
\hline Xeriscaping and Grey Water & 0.561 & 0.685 & 0.039 \\
\hline High Plains aquifer and GMDs & 0.804 & 0.353 & 0.050 \\
\hline KWO, Vision, and Kansas Aqueduct & 0.617 & 0.619 & 0.036 \\
\hline Agriculture as biggest water user in Kansas & 0.349 & 0.581 & 0.057 \\
\hline Indoor water-saving appliances & & & 0.052 \\
\hline Low-flow showerhead & 0.732 & 0.458 & 0.050 \\
\hline Low-flow toilet & 0.728 & 0.184 & 0.052 \\
\hline Water-efficient washing machine & 0.591 & 0.178 & \\
\hline Outdoor water-saving appliances & & & 0.064 \\
\hline Timed sprinklers & 0.736 & 0.835 & 0.064 \\
\hline Drip irrigation & 0.736 & 1.516 &
\end{tabular}


Table A3. Standardized model results of owning water-saving appliances for appliances for indoor and outdoor usage regressed on awareness levels for well owners $(n=407)$.

\begin{tabular}{llll}
\hline & Factor Loadings & Residual Variance & S.E. \\
\hline Awareness & & & \\
\hline Xeriscaping and Grey Water & 0.440 & 0.806 & 0.047 \\
\hline High Plains aquifer and GMDs & 0.746 & 0.444 & 0.066 \\
\hline KWO, Vision, and Kansas Aqueduct & 0.543 & 0.705 & 0.050 \\
\hline Agriculture as biggest water user in Kansas & 0.349 & 0.581 & 0.057 \\
\hline Indoor water-saving appliances & & & 0.053 \\
\hline Low-flow showerhead & 0.709 & 0.458 & 0.051 \\
\hline Low-flow toilet & 0.714 & 0.184 & 0.052 \\
\hline Water-efficient washing machine & 0.579 & & \\
\hline Outdoor water-saving appliances & & 0.835 & 0.103 \\
\hline Timed sprinklers & 0.437 & 1.516 & 0.103 \\
\hline Drip irrigation & 0.437 & & \\
\hline
\end{tabular}

Table A4. Standardized model results of owning water-saving appliances for appliances for indoor and outdoor usage regressed on awareness levels for well owners without municipal utility connections $(\mathrm{n}=141)$.

\begin{tabular}{llll}
\hline & Factor Loadings & Residual Variance & S.E. \\
\hline Awareness & & & 0.885 \\
\hline Xeriscaping and Grey Water & 0.340 & 0.313 & 0.068 \\
\hline High Plains aquifer and GMDs & 0.829 & 0.689 & 0.099 \\
\hline KWO, Vision, and Kansas Aqueduct & 0.558 & 0.118 & 0.074 \\
\hline Agriculture as biggest water user in Kansas & 0.495 & -0.019 & 0.088 \\
\hline Indoor water-saving appliances & & -0.217 & 0.086 \\
\hline Low-flow showerhead & 0.750 & -0.237 & 0.087 \\
\hline Low-flow toilet & 0.803 & & 0.084 \\
\hline Water-efficient washing machine & 0.575 & 0.709 & 0.100 \\
\hline Outdoor water-saving appliances & & 0.967 & 0.100 \\
\hline Timed sprinklers & 0.562 & & \\
\hline Drip irrigation & 0.562 & & \\
\hline
\end{tabular}

Table A5. Standardized model results of owning water-saving appliances for appliances for indoor and outdoor usage regressed on awareness levels for well owners with municipal utility connections $(\mathrm{n}=246)$.

\begin{tabular}{llll}
\hline & Factor Loadings & Residual Variance & S.E. \\
\hline Awareness & & & \\
\hline Xeriscaping and Grey Water & 0.336 & 0.887 & 0.065 \\
\hline High Plains aquifer and GMDs & 0.829 & 0.313 & 0.118 \\
\hline KWO, Vision, and Kansas Aqueduct & 0.542 & 0.707 & 0.065 \\
\hline Agriculture as biggest water user in Kansas & 0.495 & 0.117 & 0.088 \\
\hline Indoor water-saving appliances & & & 0.019 \\
\hline Low-flow showerhead & 0.697 & -0.217 & 0.077 \\
\hline Low-flow toilet & 0.747 & -0.237 & 0.076 \\
\hline Water-efficient washing machine & 0.535 & & 0.077 \\
\hline Outdoor water-saving appliances & & 0.079 & 0.120 \\
\hline Timed sprinklers & 0.382 & 0.967 & 0.120 \\
\hline Drip irrigation & 0.382 & & \\
\hline
\end{tabular}


Table A6. Standardized model results of owning water-saving appliances for appliances for indoor and outdoor usage regressed on awareness levels for domestic well owners ( $n=145)$.

\begin{tabular}{llll}
\hline & Factor Loadings & Residual Variance & S.E. \\
\hline Awareness & & & 0.060 \\
\hline Xeriscaping and Grey Water & 0.332 & 0.527 & 0.095 \\
\hline High Plains aquifer and GMDs & 0.687 & 0.657 & 0.069 \\
\hline KWO, Vision, and Kansas Aqueduct & 0.586 & 0.302 & 0.081 \\
\hline Agriculture as biggest water user in Kansas & 0.499 & & 0.078 \\
\hline Indoor water-saving appliances & & 0.036 & 0.079 \\
\hline Low-flow showerhead & 0.711 & -0.173 & 0.087 \\
\hline Low-flow toilet & 0.795 & -0.195 & 0.127 \\
\hline Water-efficient washing machine & 0.595 & & 0.127 \\
\hline Outdoor water-saving appliances & & 1.054 & \\
\hline Timed sprinklers & 0.627 & 0.627 & \\
\hline Drip irrigation & & & \\
\hline
\end{tabular}

Table A7. Standardized model results of owning water-saving appliances for appliances for indoor and outdoor usage regressed on awareness levels for lawn and garden well owners $(n=135)$.

\begin{tabular}{llll}
\hline & Factor Loadings & Residual Variance & S.E. \\
\hline Awareness & & & 0.897 \\
\hline Xeriscaping and Grey Water & 0.320 & 0.485 & 0.067 \\
\hline High Plains aquifer and GMDs & 0.718 & 0.634 & 0.073 \\
\hline KWO, Vision, and Kansas Aqueduct & 0.605 & 0.302 & 0.081 \\
\hline Agriculture as biggest water user in Kansas & 0.499 & 0.036 & 0.079 \\
\hline Indoor water-saving appliances & & -0.173 & 0.091 \\
\hline Low-flow showerhead & 0.696 & -0.195 & 0.085 \\
\hline Low-flow toilet & 0.777 & & 0.246 \\
\hline Water-efficient washing machine & 0.582 & -0.518 & 0.246 \\
\hline Outdoor water-saving appliances & & 1.054 & \\
\hline Timed sprinklers & 0.379 & & \\
\hline Drip irrigation & 0.379 & & \\
\hline
\end{tabular}

Table A8. Standardized model results of owning water-saving appliances for appliances for indoor and outdoor usage regressed on awareness levels for feedlot well owners $(n=66)$.

\begin{tabular}{|c|c|c|c|}
\hline & Factor Loadings & Residual Variance & S.E. \\
\hline \multicolumn{4}{|l|}{ Awareness } \\
\hline Xeriscaping and Grey Water & 0.307 & 0.906 & 0.081 \\
\hline High Plains aquifer and GMDs & 0.834 & 0.305 & 0.144 \\
\hline KWO, Vision, and Kansas Aqueduct & 0.620 & 0.616 & 0.097 \\
\hline Agriculture as biggest water user in Kansas & 0.499 & 0.302 & 0.081 \\
\hline \multicolumn{4}{|l|}{ Indoor water-saving appliances } \\
\hline Low-flow showerhead & 0.591 & 0.036 & 0.108 \\
\hline Low-flow toilet & 0.660 & -0.173 & 0.120 \\
\hline Water-efficient washing machine & 0.494 & -0.195 & 0.101 \\
\hline \multicolumn{4}{|l|}{ Outdoor water-saving appliances } \\
\hline Timed sprinklers & 0.370 & 0.803 & 0.378 \\
\hline Drip irrigation & 0.370 & 1.054 & 0.378 \\
\hline
\end{tabular}


Table A9. Standardized model results of owning water-saving appliances for appliances for indoor and outdoor usage regressed on awareness levels for irrigation well owners $(n=61)$.

\begin{tabular}{llll}
\hline & Factor Loadings & Residual Variance & S.E. \\
\hline Awareness & & & \\
\hline Xeriscaping and Grey Water & 0.316 & 0.900 & 0.083 \\
\hline High Plains aquifer and GMDs & 0.838 & 0.298 & 0.150 \\
\hline KWO, Vision, and Kansas Aqueduct & 0.603 & 0.636 & 0.103 \\
\hline Agriculture as biggest water user in Kansas & 0.499 & 0.302 & 0.081 \\
\hline Indoor water-saving appliances & & 0.036 & 0.112 \\
\hline Low-flow showerhead & 0.776 & -0.173 & 0.111 \\
\hline Low-flow toilet & 0.868 & -0.195 & 0.085 \\
\hline Water-efficient washing machine & 0.650 & & 0.403 \\
\hline Outdoor water-saving appliances & & 0.803 & 0.403 \\
\hline Timed sprinklers & 0.252 & 1.054 & \\
\hline Drip irrigation & 0.252 & & \\
\hline
\end{tabular}

\section{References}

1. Richey, A.S.; Thomas, B.F.; Lo, M.-H.; Reager, J.T.; Famiglietti, J.S.; Voss, K.; Swenson, S.; Rodell, M. Quantifying renewable groundwater stress with grace. Water Resour. Res. 2015, 51, 5217-5238. [CrossRef] [PubMed]

2. Shah, T.; Molden, D.J.; Sakthivadivel, R.; Seckler, D. The global groundwater situation: Overview of opportunities and challenges. Econ. Politic. Wkly. 2000, 36, 4142-4150. [CrossRef]

3. Kallis, G. Droughts. Annu. Rev. Environ. Resour. 2008, 33, 85-188. [CrossRef]

4. Famiglietti, J.S. The global groundwater crisis. Nat. Clim. Chang. 2014, 4, 945-948. [CrossRef]

5. Haacker, E.M.K.; Kendall, A.D.; Hyndman, D.W. Water level declines in the high plains aquifer: Predevelopment to resource Senescence. Ground Water 2015, 54, 231-242. [CrossRef]

6. Padget, S. The water/energy/carbon nexus and triple bottom line solutions. Presented at the Global Water: Drought, Conservation and Security in the 21st Century Conference, Lawrence, KS, USA, 12 April 2013.

7. Steward, D.R.; Bruss, P.J.; Yang, X.; Staggenborg, S.A.; Welch, S.M.; Apley, M.D. Tapping unsustainable groundwater stores for agricultural production in the High Plains Aquifer of Kansas, projections to 2110. Proc. Natl. Acad. Sci. USA 2013, 110, E3477-E3486. [CrossRef]

8. Logan, K.E.; Brunsell, N.A.; Jones, A.R.; Feddema, J.J. Assessing spatiotemporal variability of drought in the U.S. central plains. J. Arid Environ. 2010, 74, 247-255. [CrossRef]

9. Buchanan, R.C.; Wilson, B.B.; Buddemeier, R.R.; Butler, J.J., Jr. The High Plains Aquifer. Public Information Circular 18; Kansas Geological Survey: Lawrence, KS, USA, 2015.

10. Peterson, J.; Daniel, B. High Plains regional aquifer study revisited: A 20-year retrospective for Western Kansas. Great Plains Res. 2003, 13, 179-197.

11. Ashworth, W. Ogallala Blue: Water and Life on the High Plains; W.W. Norton: New York, NY, USA, 2006.

12. Wilhite, D. Drought: Past and future. Presented at the Drought in the Life, Cultures, and Landscapes of the Great Plains, Lincoln, NE, USA, 2 April 2014.

13. Stover, S. Kansas Ogallala aquifer conservation policies. Presented at the Global Water: Drought, Conservation and Security in the 21st Century Conference, Lawrence, KS, USA, 12 April 2013.

14. Wilson, B.; Gaisheng, L.; Whittemore, D.; Butler, J.J., Jr. Smoky Hill River Valley Groundwater Model; Kansas Geological Survey: Lawrence, KS, USA, 2008. Available online: http://hercules.kgs.ku.edu/geohydro/ofr/ofr2008_20/index.htm (accessed on 1 October 2014).

15. White, W.A. Biosequestration and Ecological Diversity: Mitigating and Adapting to Climate Change and Environmental Degradation; CRC Press: Boca Raton, FL, USA, 2013.

16. Lemley, A.; Wagenet, L. Rural water quality database: Educational program to collect information. J. Ext. 1993, $31,11-13$.

17. Expert Panel on Groundwater. The Sustainable Management of Groundwater in Canada; Council of Canadian Academies: Ottawa, ON, Canada, 2009.

18. Shove, E. Comfort, Cleanliness and Convenience: The Organization of Normality; Berg Press: New York, NY, USA, 2003.

19. Southerton, D.; van Vliet, B.; Chappells, H. Introduction: Consumption, infrastructures and environmental sustainability. In Sustainable Consumption: The Implications of Changing Infrastructure Provision; Southerton, D., Chappells, H., van Vliet, B., Eds.; Edward Elgar: Northampton, MA, USA, 2004; pp. 1-11. 
20. Medd, W.; Elizabeth, S. The Sociology of Water Use; Water Industry Research Limited: London, UK, 2007.

21. Browne, A.L.; Medd, W.; Anderson, B. Developing novel approaches to tracking domestic water demand under uncertainty-a reflection on the "up scaling" of social science approaches in the United Kingdom. Water Resour. Manag. 2013, 27, 1013-1035. [CrossRef]

22. Smith, C.S. City Water, City Life: Water and the Infrastructure of Ideas in Urbanizing Philadelphia, Boston, and Chicago; University of Chicago Press: Chicago, IL, USA, 2013.

23. Hickey, D. Regional service through unity: Meeting our region's needs today and Tomorrow. Presented at the Governor's Water Conference, Manhattan, KS, USA, 14 November 2016.

24. Oskamp, S.; Harrington, M.J.; Edwards, T.C.; Sherwood, D.L.; Okuda, S.M.; Swanson, D.C. Factors influencing household recycling behavior. Environ. Behav. 1991, 23, 494-519. [CrossRef]

25. Gilg, A.W.; Stewar, B. Behavioral attitudes towards water saving? evidence from a study of environmental Actions. Ecol. Econ. 2006, 57, 400-414.

26. Barr, S.; Gilg, A.W. A conceptual framework for understanding and analyzing attitudes towards environmental behavior. Hum. Geogr. 2007, 89, 361-379.

27. Baldassare, M.; Katz, C. The personal threat of environmental problems as predictor of environmental practices. Environ. Behav. 1992, 24, 602-616. [CrossRef]

28. De Young, R. Some psychological aspects of reduced consumption behavior: The role of intrinsic motivation and competence motivation. Environ. Behav. 1996, 28, 358-409. [CrossRef]

29. Fox, M.A.; Nachman, K.E.; Anderson, B.; Lam, J.; Resnick, B. Meeting the public health challenge of protecting private wells: Proceedings and recommendations from an expert panel workshop. Sci. Total. Environ. 2016, 555, 113-118. [CrossRef]

30. Warde, A. Consumption and theories of practice. J. Consum. Cult. 2005, 5, 131-153. [CrossRef]

31. Stillerman, J. The Sociology of Consumption: A Global Approach; Polity Press: Malden, MA, USA, 2015.

32. Warde, A. The Practice of Eating; Polity Press: Malden, MA, USA, 2016.

33. Lave, J.; Wenger, E. Situated Learning: Legitimate Peripheral Participation; Cambridge University Press: Cambridge, UK, 1991.

34. Wenger, E. Communities of Practice: Learning, Meaning, and Identity; Cambridge University Press: Cambridge, UK, 1998.

35. Wright, L. Clean and Decent: The Fascinating History of the Bathroom and the Water Closet; Routledge and Kegan Paul: London, UK, 1960.

36. Glennon, R. Unquenchable: America's Water Crisis and What to do About It; Island Press: Washington, DC, USA, 2009.

37. Fishman, C. The Big Thirst: The Secret Life and Turbulent Future of Water; Free Press: New York, NY, USA, 2011.

38. Fine, B. The World of Consumption: The Material and Cultural Revisited, 2nd ed.; Routledge: London, UK, 2002.

39. Foth, V. Buckets, barrels, and backaches: Carrying water for the farm home. In Water and the Making of Kansas; Kansas Natural Resource Council: Topeka, KS, USA, 2010.

40. Parfit, M. Sharing the Wealth of Water. National Geographic, November 1993; 20-37.

41. Little, T.D. Mean and covariance structures (macs) analyses of cross-cultural data: Practical and theoretical issues. Multivar. Behav. Res. 1997, 32, 53-76. [CrossRef]

42. Cheung, G.W.; Rensvold, B.R. Evaluating goodness-of-fit indexes for testing measurement invariance. Struct. Equ. Modeling 2002, 9, 233-255. [CrossRef]

43. Mollinga, P. Water, Politics and development: Framing a political sociology of water resources management. Water Altern. 2008, 1, $7-23$.

44. Ternes, B.; Donovan, B. Hydrologic habitus. Nat. Cult. 2020, 15, 32-53. [CrossRef]

45. Spaargaren, G. Sustainable Consumption: A theoretical and environmental policy perspective. In Sustainable Consumption: The Implications of Changing Infrastructure Provision; Southerton, D., Chappells, H., van Vliet, B., Eds.; Edward Elgar: Northampton, MA, USA, 2004; pp. 15-31.

46. Ternes, B. Groundwater citizenship and water supply awareness: Investigating water-related infrastructure and well ownership. Rural. Sociol. 2017, 83, 347-375. [CrossRef]

47. Lister, R. Citizenship: Feminist Perspectives; New York University Press: New York, NY, USA, 1997.

48. Curtin, D. Chinnagounder's Challenge: The Question of Ecological Citizenship; Indiana University Press: Indianapolis, IN, USA, 1999.

49. Darby, D.; Hossler, T.; Stock, P. New Farmers 2014/2018; P. \& T. Committee: Lawrence, KS, USA, 2019.

50. Szasz, A. Shopping Our Way to Safety: How We Changed from Protecting the Environment to Protecting Ourselves; University of Minnesota Press: Minneapolis, MN, USA, 2007.

51. Mehta, L.; Synne, M. Liquid Dynamics: Challenges for Sustainability in the Water Domain. In Water and Development: Good Governance after Neoliberalism; Munck, R., Asignwire, M., Fagan, H., Kabonesa, C., Eds.; Zed Books: London, UK, 2015; pp. 30-59.

52. Ternes, B. Saving for a dry day: Investigating well ownership and watering practices during droughts. Environ. Sociol. 2018, 5, 93-107. [CrossRef]

53. Yeboah, F.K.; Michael, D.K. Explaining energy conservation and environmental citizenship behaviors using the value-belief-norm framework. Hum. Ecol. Rev. 2016, 22, 137-159.

54. Catton, W.R.; Dunlap, R.E. Environmental sociology: A new paradigm. Am. Behav. Sociol. 1978, 13, 41-49.

55. Catton, W.R.; Dunlap, R.E. A New ecological paradigm for post-exuberant sociology. Am. Behav. Sci. 1980, 24, 15-47. [CrossRef] 